\title{
Covid-19 Cases Growth and Business Continuity in Indonesia: A Causality Test
}

Silvi Asna Prestianawati ${ }^{1}$, Axellina Muara Setyanti ${ }^{2}$

1,2Universitas Brawijaya

\begin{abstract}
The objective of this study is to examine the causality between Covid-19 cases growth and business continuity in Indonesia, thus can be formulated the postCovid business strategies. The Covid-19 cases are modeled into 'daily case' and 'active case', while business continuity proxied with human mobility to grocery and pharmacy, also to retail and recreation. Using daily data ranging from March to December 2020, the Granger causality results show that there is a bidirectional causality between daily case and grocery-pharmacy business, whereas interestingly there is a unidirectional relationship from retail-recreation business to daily case. In active case model, author found a unidirectional causality from active case to both grocery-pharmacy and retail-recreation business. This research may be used to improve business strategy in order to maintain the business life during the Covid-19 Pandemic in Indonesia.
\end{abstract}

\author{
KEYWORDS \\ Business; Covid- \\ 19; Granger \\ causality; \\ Human mobility
}

\section{INTRODUCTION}

The coronavirus epidemic is principally a human catastrophe, affecting millions of people worldwide. The coronavirus 2019 (COVID-19) pandemic has brought major disruptions worldwide, with further impacts yet to be felt. For many businesses, operations are curtailed or dramatically shifted, and supply chains are disrupted (Charles, 2020).

The COVID-19 pandemic has advanced rapidly since January 2020, with overwhelming consequences to people and businesses throughout the world. The Institute of Chartered Accountant of England and Wales (ICAEW, 2020) reports that COVID-19 is not just a world health emergency; it is an economic one too. Also in the view of the audit giant Ernst \& Young (2020), businesses are dealing with lost revenue and disrupted supply chains and there has been significant volatility in financial markets.

As the number of cases of the COVID-19 increases, the focus of companies must be on limiting the direct impact on employees and customers while also supporting efforts to limit the spread of the virus. The healthcare sector, airlines, travel firms, and 
supermarkets are experiencing the immediate impact, and face a huge challenge over the coming weeks to respond effectively to the emerging crisis.

\section{Covid-19 Cases in Indonesia}

Indonesia has the death number because of COVID-19 much higher than People's Republic of China (Setiati \& Azwar, 2020). It is because Indonesia does not has well preparation to face COVID-19. So that in the beginning of COVID-19 Indonesia has massive preparation about the hospital or health care. During the increasing of COVID19 cases, Indonesia government implemented large-scale social restriction in each cities as the effort to decrease the cases specially the death. The government also order the people to stay at home. Those programs strictly implemented in all area in Indonesia (Pitaloka, Al Umar, Hartati, \& Fitria, 2020).

Figure 1. Covid-19 Active Cases and Daily Cases in Indonesia March $2^{\text {nd }}-$ December $7^{\text {th }} 2020$

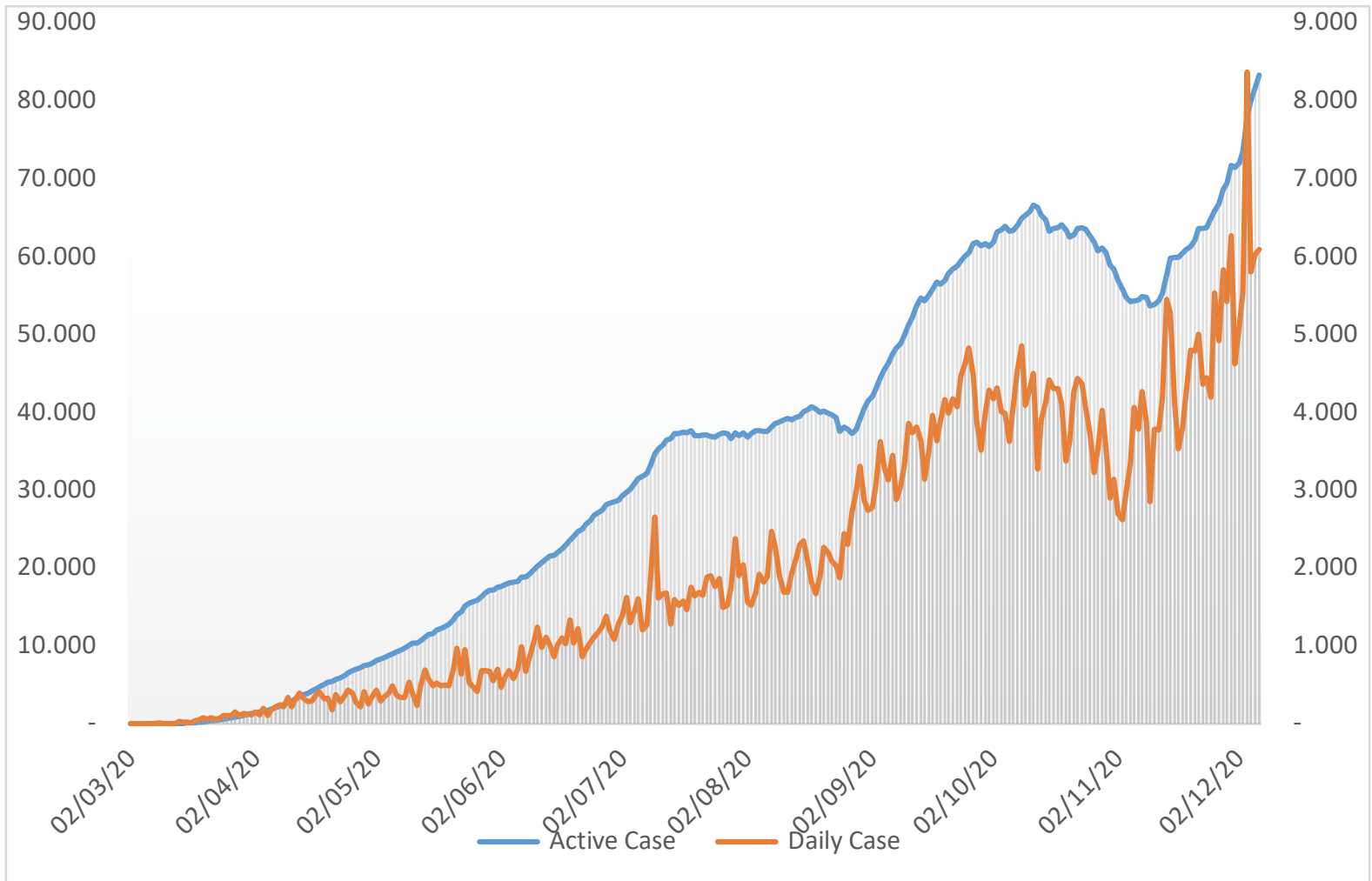

Source: Satgas Penanganan Covid (2020), processed

\section{Human Mobility to Several Places in Indonesia}

Figure 1 showed that the cases of COVID-19 increased day by day (fluctuated). Active cases in Indonesia was going much higher than the daily cases. It because the convalescence process take more time because of the limitation of the healthcare. Setiati \& Azwar (2020) mentioned that only 309,100 hospital's beds in Indonesia in which most of them exist in Java. It means that the health care disparity problem happened as well. 


\section{Human Mobility to Several Places in Indonesia}

The widespread closing of stores and businesses in Indonesia and around the world due to the corona virus is unprecedented. Stores, factories and many other businesses have closed by policy mandate or downward demand shifts. Many of these closures may be permanent because of the inability to pay ongoing expenses and survive the shutdown. The impact on businesses around the world is likely to be severe.

In Indonesia, the central and local governments have tried to suppress the transmission of the Covid-19 virus since March 2020 through the implementation of large-scale social restrictions (PSBB). The PSBB policy is listed in Government Regulation (PP) Number 21 of 2020 concerning PSBB in the Context of Accelerating the Handling of Covid-19. PSBB has the right to limit the movement of people and goods across provinces, districts or cities, as well as school and work vacations, restrictions on religious activities, and restrictions on activities in public places and facilities.

Figure 2. Human Mobility to Grocery-Pharmacy and Retail-Recreation Places March $2^{\text {nd }}$ December $7^{\text {th }} 2020$

1000

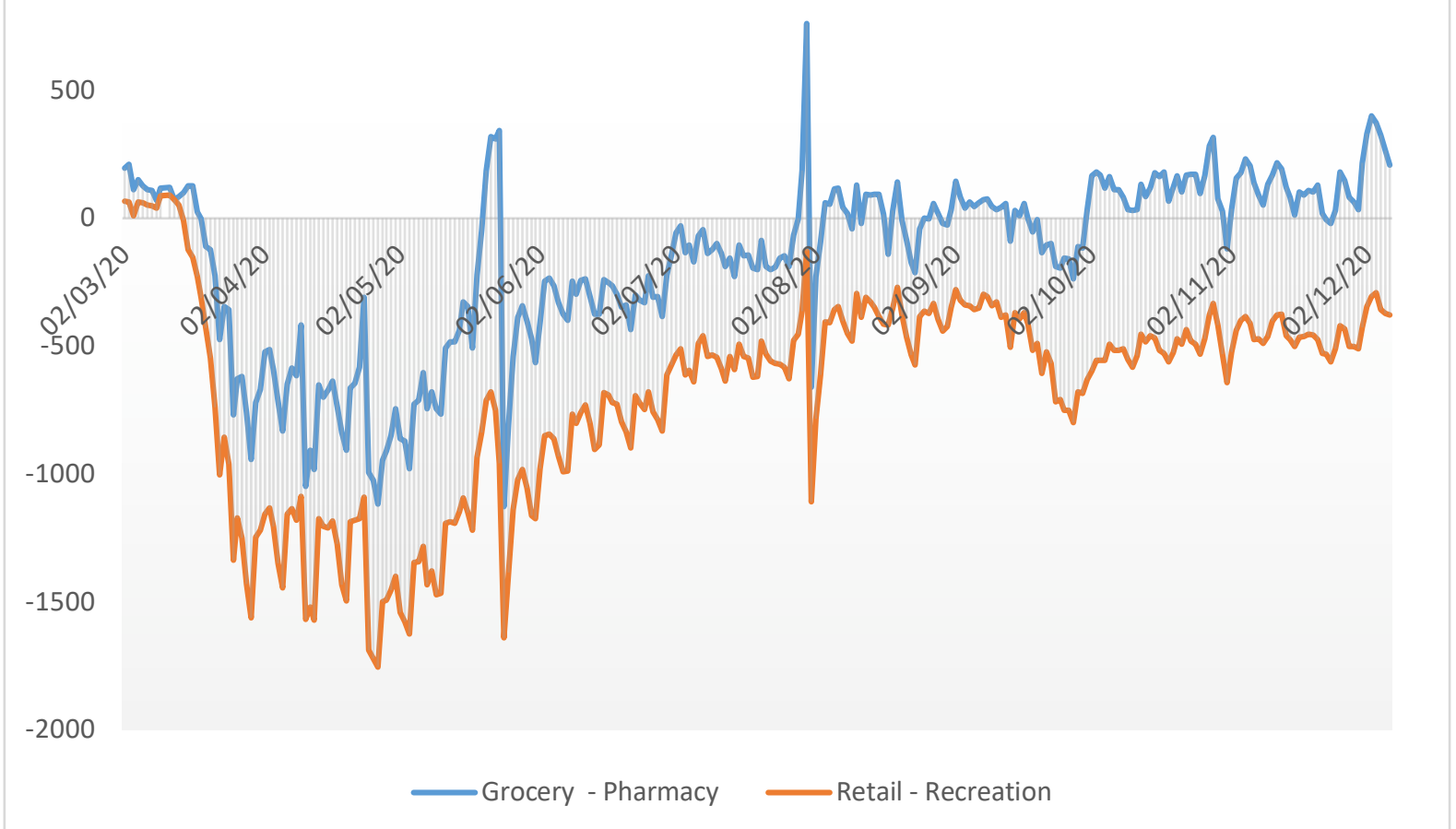

Source: Google Mobility Index (2020), processed

\section{Human Mobility Restrictions and the Shifting Business Strategies}

The high of COVID-19 cases in Indonesia did not reflect that Indonesian people did not obey the government rules or policies to decrease the COVID-19 cases. Because based on figure 2, the human or people mobility since COVID-19 come until December 2020 was low. The fear about the virus cause people decide only stay at home and doing their job at home. The fact showed in June and August people started to come outside but they come to grocery and pharmacy to buy their primary and health needs. Surprisingly, 
people in Indonesia really stay away from the crowded things such as leisure place that is retail and recreation to avoid the COVID-19 transmission.

\section{Human Mobility Restrictions and the Shifting Business Strategies}

The impact of crisis such in Covid-19 on a business enterprise should be of great concern to entrepreneurs as it affects current and future business performance (Fabeil, 2020). Statistics have shown that about three out of four businesses without a continuity plan will fail within three years after a disaster or crisis strikes (Cook, 2015).

The impact of crisis such in Covid-19 on a business enterprise should be of great concern to entrepreneurs as it affects current and future business performance (Fabeil, 2020). Statistics have shown that about three out of four businesses without a continuity plan will fail within three years after a disaster or crisis strikes (Cook, 2015). As the figure 2 proven that the human mobility especially to the leisure place is very minimum or almost zero. This phenomenon actually not only impacted to recreation place or retail, but also it impacted to other business sectors for example restaurant, public transportation and beauty. As mentioned before that almost all business sectors scale down and many of them closed their business. Donthu \& Gustafsson (2020) found that the main cause of many business closed during the pandemic is they could not able to finance their operational activity because of the low sales and affect to their income.

In this problem, the only thing that the business can do is they must shift or change their business strategies to adjust with the pandemic condition (Donthu \& Gustafsson, 2020). Some research mentioned the solution to sustain the business during the COVID-19. Alves, Lok, Luo, \& Hao (2020); Bansal, Grewatsch, \& Sharma (2021); Bartik et al., (2020); Craven, Liu, Mysore, \& Wilson (2020) suggest the business to protect their employee and move to digital platform. They found both suggestions from the economic root problem. In this paper, author would to find the business strategies based on other perspective that is human mobility as the root problem. Because the authors believe that the basic problem of the sales decreasing is the change of human behaviour as the customer. This paper should implicate to find the new insight of business strategies during the pandemic in order to keep the business sustain and recover the economic outbreak as soon as possible.

\section{METHOD}

This study is attempted to examine the link between business continuity that reflected by human mobility to the business and covid-19 cases in Indonesia. The human mobility and covid-19 data are daily data obtained from Google Mobility Index and Satgas Penanganan Covid Indonesia (covid19.go.id). The data containing 281 daily series, ranged from March $2^{\text {nd }}, 2020$ to December $7^{\text {th }}, 2020$. The estimation in this study will be carried out in two 
stages, namely the unit root test and causality testing using the Granger Causality approach.

\section{Unit Root Test}

Stationarity is one of the important prerequisites in the econometrics model using time series data. Stationary data is data that shows the mean and variance remains the same at any time the data is used, meaning that with stationary data the model with time series data can be said to be more stable. If the data used in the model is not stationary, then the validity and stability of the data are reconsidered.

\section{Granger Causality Test}

The Granger causality test is used to test the causality relationship between two variables in the regression, which in this case are human mobility, representing business continuity and Covid-19 cases. The basic Granger causality equation model is as follows:

$$
\begin{aligned}
& Y_{t}=\sum_{i=1}^{m} \alpha_{i} Y_{t-1}+\sum_{j=1}^{m} \beta_{j} X_{t-j}+v_{t} \\
& X_{t}=\sum_{i=1}^{m} \alpha_{i} X_{t-1}+\sum_{j=1}^{m} \beta_{j} Y_{t-j}+v_{t}
\end{aligned}
$$

Where:

Y : Human mobility (to Grocery - Pharmacy and to Retail - Recreation)

$\mathrm{X} \quad$ : Covid-19 cases (Daily Cases and Active Cases)

m : number of lag

$\alpha, \beta \quad$ : variables coefficient

$\mathrm{v} \quad$ : error term

There are sixteen possible cases of this causality relationship, so that the following sixteen hypotheses are formed:

H1 : There is an unidirectional causality of human mobility to Grocery - Pharmacy affecting Covid-19 Daily Cases

H2 : There is an unidirectional causality of Covid-19 Daily Cases affecting human mobility to Grocery - Pharmacy

H3 : There is a bidirectional causality relationship, human mobility to Grocery Pharmacy and Covid-19 Daily Cases influence each other

H4 : There is an independent relationship/no relationship between human mobility to Grocery - Pharmacy and Covid-19 Daily Cases

H5 : There is an unidirectional causality of human mobility to Grocery - Pharmacy affecting Covid-19 Active Cases

H6 : There is an unidirectional causality of Covid-19 Active Cases and human mobility to Grocery - Pharmacy affecting

H7 : There is a bidirectional causality relationship, human mobility to Grocery Pharmacy and Covid-19 Active Cases influence each other 
H8 : There is an independent relationship/no relationship between human mobility to Grocery - Pharmacy and Covid-19 Active Cases

H9 : There is an unidirectional causality of human mobility to Retail - Recreation affecting Covid-19 Daily Cases

H10 : There is an unidirectional causality of Covid-19 Daily Cases affecting human mobility to Retail - Recreation

H11 : There is a bidirectional causality relationship, human mobility to Retail Recreation and Covid-19 Daily Cases influence each other

H12 : There is an independent relationship/no relationship between human mobility to Retail - Recreation and Covid-19 Daily Cases

H13 : There is an unidirectional causality of human mobility to Retail - Recreation affecting Covid-19 Active Cases

H14 : There is an unidirectional causality of Covid-19 Active Cases affecting human mobility to Retail - Recreation

H15 : There is a bidirectional causality relationship, human mobility to Retail Recreation and Covid-19 Active Cases influence each other

H16 : There is an independent relationship/no relationship between human mobility to Retail - Recreation and Covid-19 Active Cases

\section{RESULT AND DISCUSSION}

\section{Unit Root Test}

Firstly, all the data used in the previous causality test was carried out by unit root tests based on the 5 percent degree of confidence. The results of the unit root test by comparing the probability results with a critical value are as follows:

Table 1. Unit Root Test Results

\begin{tabular}{llclll}
\hline \multirow{2}{*}{ Variables } & \multicolumn{5}{c}{ Augmented Dickey-Fuller Unit Root Test } \\
\cline { 2 - 6 } & t-stat & $\mathbf{1 \%}$ & $\mathbf{5 \%}$ & $\mathbf{1 0 \%}$ & \multicolumn{1}{c}{ Conclusion } \\
\hline Covid-19 Daily Cases & $-1,508$ & $-3,458$ & $-2,879$ & $-2,570$ & $\begin{array}{l}\text { Not stationary in } \\
\text { level }\end{array}$ \\
& $-6,298$ & $-3,989$ & $-3,429$ & $-3,130$ & $\begin{array}{l}\text { Stationary in } \\
\text { first difference }\end{array}$ \\
Covid-19 Active & 2,324 & $-3,458$ & $-2,879$ & $-2,570$ & $\begin{array}{l}\text { Not stationary in } \\
\text { level }\end{array}$ \\
Cases & $-10,933$ & $-3,458$ & $-2,879$ & $-2,570$ & $\begin{array}{l}\text { Stationary in } \\
\text { first difference } \\
\text { Grocery - Pharmacy }\end{array}$ \\
& $-6,152$ & $-3,989$ & $-3,429$ & $-3,130$ & $\begin{array}{l}\text { Stationary In } \\
\text { level }\end{array}$ \\
Retail - Recreation & $-3,929$ & $-3,989$ & $-3,429$ & $-3,130$ & $\begin{array}{l}\text { Stationary in } \\
\text { level }\end{array}$ \\
\hline
\end{tabular}


From the test results above, it can be interpreted that the human mobility variables both to Grocery - Pharmacy and Retail - Recreation are stationary at the level, while the Covid-19 Daily Cases and Active Cases are stationary at the first difference, both in the ADF test approach. Because all data have been stationary, it can be continued to test the causality.

\section{Granger Causality Test}

Next, in this research, Granger causality test of business continuity and covid-19 cases were used, where an exogenous variable can be treated as an endogenous variable. In identifying the causal relationship between the two variables, the degree of confidence considered is also 5 percent. The results are following:

Table 2. Granger Causality Test Results

\begin{tabular}{|c|c|c|c|}
\hline & Chi2 & Prob & Conclusion \\
\hline $\begin{array}{l}\text { Grocery - } \\
\text { Pharmacy to } \\
\text { Daily Case } \\
\text { Daily Case to } \\
\text { Grocery - } \\
\text { Pharmacy }\end{array}$ & 10,220 & $0,010^{*}$ & $\begin{array}{l}\text { There is a bidirectional } \\
\text { causality between human } \\
\text { mobility to Grocery - } \\
\text { Pharmacy and Covid-19 } \\
\text { Daily Cases. }\end{array}$ \\
\hline $\begin{array}{l}\text { Retail - } \\
\text { Recreation to } \\
\text { Daily Case } \\
\text { Daily Case to } \\
\text { Retail - } \\
\text { Recreation }\end{array}$ & 4,048 & 0,132 & $\begin{array}{l}\text { There is a unidirectional } \\
\text { causality that human } \\
\text { mobility to Retail - } \\
\text { Recreation affecting } \\
\text { Covid-19 Daily Cases. }\end{array}$ \\
\hline $\begin{array}{l}\text { Grocery - } \\
\text { Pharmacy to } \\
\text { Active Case } \\
\text { Active Case to } \\
\text { Grocery - } \\
\text { Pharmacy }\end{array}$ & 18,539 & $0,000^{*}$ & $\begin{array}{l}\text { There is a unidirectional } \\
\text { causality that Covid-19 } \\
\text { Active Cases affecting } \\
\text { human mobility to } \\
\text { Grocery - Pharmacy. }\end{array}$ \\
\hline $\begin{array}{l}\text { Retail - } \\
\text { Recreation to } \\
\text { Active Case } \\
\text { Active Case to } \\
\text { Retail - } \\
\text { Recreation }\end{array}$ & 9,265 & $0,010^{*}$ & $\begin{array}{l}\text { There is a unidirectional } \\
\text { causality that Covid-19 } \\
\text { Active Cases affecting } \\
\text { human mobility to Retail - } \\
\text { Recreation. }\end{array}$ \\
\hline
\end{tabular}


Source: Data estimation (2020)

\section{Human Mobility and Covid-19 Cases}

The causality test shows that there is a bidirectional causality between human mobility to Grocery - Pharmacy and Covid-19 Daily Cases, meanwhile to active case, there is a unidirectional causality that Covid-19 Active Cases affecting human mobility to Grocery - Pharmacy. It means that the intensity of human mobility outside the house leading to increase in daily cases of Covid-19, and the information about active cases tends to create awareness of people to stay at home, thus when the active case increases, the human mobility decreases.

Next, the causality test concludes that there is a unidirectional causality that human mobility to Retail - Recreation affecting Covid-19 Daily Cases, and so does in active case there is a unidirectional causality that Covid-19 Active Cases affecting human mobility to Retail - Recreation. Similar with Iacus et al (2020), these results show that the spreading of the virus and human mobility are connected.

The implementation of policies to restrict human mobility is considered the right step to mitigate the spread of covid-19, as has been found in several studies such as in Kraemer et al (2020), besides precautionary behavior (as in Chan et al, 2020) aimed to decrease human mobility that also improve the containment of the spread of the virus.

\section{Business Adaptability and Continuity towards Covid-19}

Risk-taking attitudes and behaviors are important elements of human behavior as they determine a range of decision-making strategies (Rieger et al, 2015), including towards a dangerous situation such as Covid-19. Feelings elicited during a pandemic have an impact on everyday activities, for example shopping or going to recreational spots. People are forced to make trade-off that are affected by their risk behavior (Chan et al, 2020). Risk attitudes matter as individuals are aware that going into public places increases the possibility of being infected. Prior to that, people started adjusting their mobility and consumption behavior (Chan et al, 2020; Kantar, 2020).

In many countries, the reduced mobility behavior has led to an effect on economic activities such as the closure of business (Karabag, 2020). Entrepreneurs experience business cancellation or closure and reduced income due to the mobility control (Fabeil et al, 2020), so businesses are forced to make an adaptation to keep their continuity. One of the most popular as a shift in business strategy is contact-free economy or low-touch economy. The term low-touch economy refers to a phenomenon that is independent of face-to-face contact between customers and salespeople. For example, as in Fabeil et al (2020), digitalized marketing through mobile applications and social media, such as Facebook, Instagram, WhatsApp are more common in the period of Covid-19. In Europe, as of early April 2020 13\% of consumers said they were browsing e-commerce for the 
first time. In Italy, e-commerce transactions have increased by $81 \%$ since the end of February 2020 (Albinsaid, 2020). Cagliano et al (2003) results show a close link between the use of Internet tools and the level of integration with customers and suppliers. Even the luxury industry, has been putting online shopping at the forefront of their marketing efforts, while still providing the lavish shopping experience consumers expect from luxury retailers. The low-touch economy has created a digital revolution in the luxury industry (TDF Asia, 2020).

Besides that, more offline merchants are accepting payment via bank transfer or e-wallet. Businesses that survive the Covid-19 pandemic will be those that rely on business models tailored to this new normal while keeping everyone as safe as possible. In accordance to that, grocery, pharmacy, retail, and recreation business that might be dominated by SMEs supposed to use technology and hence digital transformations to keep up the continuity. In fact, SMEs are most vulnerable during the outbreak since they tend to have a lower capital reserve, fewer assets, and lower levels of productivity than larger firms (OECD, 2020). In China's experience (Wang et al, 2020), firms are independently integrate and reconfigure their offline resources and conduct marketing innovation by transferring the original marketing channels of their existing business to online channels. This transfer provides the opportunity to maintain the normal operation of their existing business while responding successfully to the rapidly changing purchasing patterns of customers during the COVID-19. For example, Alibaba Group launched grocery shopping with contactless distribution at its widespread gas station outlets (Cuba, 2020).

Indonesia as the large countries with huge investment (business) should take the new strategies to sustain the business during the COVID-19. The business life give multiplayer effect to other economic sectors such as poverty, unemployment, inflation and etc. Using the human mobility perspective, this paper support what Lim \& Zohren (2020); McNeish \& Hamaker (2020) and Pitaloka et al., (2020) suggest to business in Indonesia in order to survive during the pandemic that are the improvement of digitalization of their system and low touch economy. They could move to sell their product via e-commerce and follow the recent marketing trend by using social media such as TikTok and Instagram. Moreover, low touch economy actually follow the human mobility pattern. People has a big fear to come outside to visit the crowed such as the shopping center. Low touch economy will help people to strengthen their health protection and minimize their concern to come to do daily activities in the new normal era. So that, this paper may contribute to provide further insight about the business strategies during the pandemic with human mobility perspective and help business in Indonesia keep survive for better economy recovery.

\section{CONCLUSION}

It concluded that human mobility during the COVID-19 to grocery and pharmacy as well as to retail and recreation center are low. But, in June and August 2020 found the human 
mobility to grocery and pharmacy was increased. It probably caused by there was Eid AlFitr in June and, in August in 2020 has Indonesian Independence Day that may attracted people to come to grocery and also improve their health needs (come to grocery). Furthermore, Indonesian people keeping stay away from the crowded place that are retail and recreation center to protect their self from COVID-19 transmission.

\section{REFERENCES}

Albinsaid, Gamal. (2020). Kebangkitan Low Touch Economy Saat Pandemi Covid-19. Retrieved from https://kumparan.com/gamalalbinsaid/kebangkitan-low-toucheconomy-saat-pandemi-covid-19-1td6wrIcVem/full.

Alves, J. C., Lok, T. C., Luo, Y., \& Hao, W. (2020). Crisis management for small business during the COVID-19 outbreak: Survival, resilience and renewal strategies of firms in Macau.

Bansal, P., Grewatsch, S., \& Sharma, G. (2021). How COVID-19 informs business sustainability research: It's time for a systems perspective. Journal of Management Studies, 58(2), 602-606.

Bartik, A. W., Bertrand, M., Cullen, Z., Glaeser, E. L., Luca, M., \& Stanton, C. (2020). The impact of COVID-19 on small business outcomes and expectations. Proceedings of the National Academy of Sciences, 117(30), 17656-17666.

Cagliano, R., Caniato, F. and Spina, G. (2003), E-business strategy: How companies are shaping their supply chain through the Internet, International Journal of Operations \& Production Management, Vol. 23 No. 10, pp. 1142-1162.

Chan, H. F., Skali, A., Savage, D. A., Stadelmann, D., \& Torgler, B. (2020). Risk attitudes and human mobility during the COVID-19 pandemic. Scientific reports, 10(1), 1-13.

Charles, S. (2020). COVID-19 Impacts on Accounting, Reporting and Internal Controls. Protivitilnc publication.Retrieved from, https://blog.protiviti.com/2020/04/01/covid-19-impacts-on-accountingreporting-and-internal-controls/.

Cook, J. (2015). A six-stage business continuity and disaster recovery planning cycle. SAM Advanced Management Journal, 80(3), 22-33.

Craven, M., Liu, L., Mysore, M., \& Wilson, M. (2020). COVID-19: Implications for business. McKinsey \& Company, 1-8.

Cuba, L. (2020). What is the purpose of Sinopec that selling fresh products at gas stations? https://www.huxiu.com/article/340189.html.

Donthu, N., \& Gustafsson, A. (2020). Effects of COVID-19 on business and research. Journal of Business Research, 117, 284.

Ernst \& Young (2020). COVID-19 business continuity plan: Five ways to reshape. EY, Canada. EY publication. Retrieved from, 
https://www.ey.com/en_ca/transactions/companies-can-reshape-results-andplan-for-covid-19-recovery.

Lim, B., \& Zohren, S. (2020). Time series forecasting with deep learning: A survey. ArXiv Preprint ArXiv:2004.13408.

Fabeil, N. F., Pazim, K. H., \& Langgat, J. (2020). The impact of Covid-19 pandemic crisis on micro-enterprises: Entrepreneurs' perspective on business continuity and recovery strategy. Journal of Economics and Business, 3(2).

Kantar. (2020). Coronavirus outbreak's impact on China's consumption. Retrieved from https://mp.weixin.qq.com/s/OptUHteL3zGVHahnDolRDg.

Karabag, S. F. (2020). An unprecedented global crisis! the global, regional, national, political, economic and commercial impact of the coronavirus pandemic, Journal of Applied Economics and Business Research,10 (1), 1-6.

Kraemer, M. U., Yang, C. H., Gutierrez, B., Wu, C. H., Klein, B., Pigott, D. M., ... \& Scarpino, S. V. (2020). The effect of human mobility and control measures on the COVID-19 epidemic in China. Science, 368(6490), 493-497.

Lacus, S. M., Santamaria, C., Sermi, F., Spyratos, S., Tarchi, D., \& Vespe, M. (2020). Human mobility and COVID-19 initial dynamics. Nonlinear Dynamics, 101(3), 1901-1919.

McNeish, D., \& Hamaker, E. L. (2020). A primer on two-level dynamic structural equation models for intensive longitudinal data in Mplus. Psychological Methods, 25(5), 610.

OECD (2020). Coronavirus (COVID-19). SME policy responses. Available at: https://read. oecd-ilibrary.org/view/?ref=119_119680di6h3qgi4x\&title=Covid19_SME_Policy_Responses

Rieger, M.O., Wang,M. \& Hens, T. (2015) Risk preferences around the world. Manag. Sci. 61, 637-648.

Pitaloka, H., Al Umar, A. U. A., Hartati, E. R., \& Fitria, D. (2020). The economic impact of the COVID-19 outbreak: Evidence from Indonesia. Jurnal Inovasi Ekonomi, 5(02).

Setiati, S., \& Azwar, M. K. (2020). COVID-19 and Indonesia. Acta Medica Indonesiana, 52(1), 84-89.

The Institute of Chartered Accountant of England and Wales-ICAEW (2020). UK practical business advice: COVID-19. Retrieved from, https://www.icaew.com/coronavirus/uk-practical-business-advice-covid-19.

Tour De Force (TDF Asia). (2020). Why does the Low-Touch Economy Matter in the Luxury Industry?. Retrieved from https://tdf-asia.com/tdf-vm-blog-opinioninsights-live-with-tdf/why-does-the-low-touch-economy-matter-in-the-luxuryindustry-shop-window-display-harmonised-retail/. 
Wang, Y., Hong, A., Li, X., \& Gao, J. (2020). Marketing innovations during a global crisis: A study of China firms' response to COVID-19. Journal of Business Research, 116, 214-220. 